The crisis and national labour law reforms: a mapping exercise

-

Stefan Clauwaert

Isabelle Schömann

Working Paper 2012.04

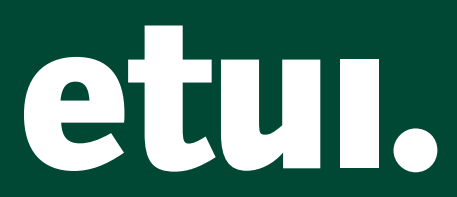




\section{The crisis and national labour law reforms: a mapping exercise}

Stefan Clauwaert

Isabelle Schömann 
Stefan Clauwaert and Isabelle Schömann are senior researchers at the European Trade Union Institute (ETUI) in Brussels.

This Working Paper presents the main trends and tendencies based on a country by country analysis. The country studies are regularly updated and can be found at the ETUI website: http://www.etui.org/Topics/Social-dialogue-collective-bargaining/Social-legislation

Brussels, 2012

๑ Publisher: ETUI aisbl, Brussels

All rights reserved

Print: ETUI Printshop, Brussels

D/2012/10.574/16

ISSN 1994-4446 (print version)

ISSN 1994-4454 (pdf version)

The ETUI is financially supported by the European Union. The European Union is not responsible for any use made of the information contained in this publication. 


\section{Contents}

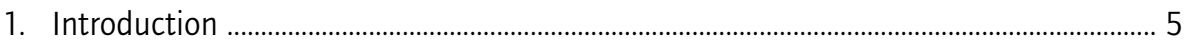

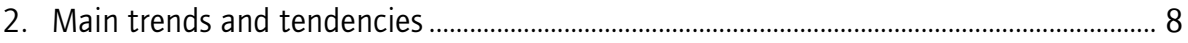

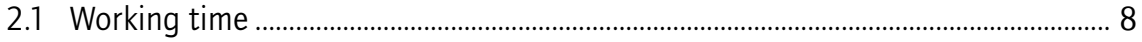

2.2 Atypical contracts (fixed-term, part-time and temporary agency work) and the introduction of new types of contract ...................................................... 10

2.3 Redundancy rules .............................................................................................. 12

2.4 Changes to industrial relations and collective bargaining systems .................... 13

2.5 Lack of democratic foundations in the reform process ............................................ 14

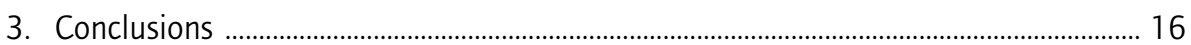

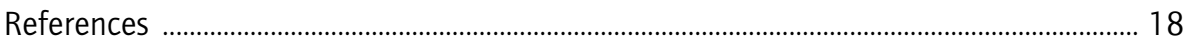





\section{Introduction}

The ETUI has covered various aspects of the economic and financial crisis in numerous publications. Valuable publications have touched upon plant-level responses to the economic crisis (Glassner et al. (2009); government and trade union responses in the financial sector (Glassner 2009); how institutions affect labour market adjustment to the crisis in various EU countries (Leschke et al. 2010); the effect of the crisis in the public sector (Glassner 2010); and wages in the crisis (O'Farrell 2010). This report focuses on labour law reforms in various European countries either triggered by the crisis or introduced using the crisis - falsely - as an excuse. ${ }^{1}$

In his address to the European Parliament on 14 September 2011, ILO Director-General Juan Somovia stated: 'Respect for fundamental principles and rights at work is non-negotiable: not even in times of crisis when questions of fairness abound. This is particularly important in countries having to adopt austerity measures. We cannot use the crisis as an excuse to disregard internationally agreed labour standards.'

At the G20 meeting of Labour and Employment Ministers on 26-27 September 2011 in Paris, promoting the effective application of social and labour rights and ensuring respect for fundamental principles and rights at work also constituted one of the key recommendations (G20 2011a) and was endorsed in the Declaration of the G2o Heads of State adopted at the Summit in Cannes on 3-4 November 2011 (G2O 2011b).

Evidence shows that since the end of 2008, the start of the economic crisis, public authorities and national legislators have taken a range of measures to boost enterprise flexibility, including amendments to national labour law. In some cases, general labour law reforms were initiated prior to the economic crisis with the professed aim of 'modernising' labour law. In some countries, such as Hungary, a change of government (shifting to the right) led to the acceleration of drastic changes in labour law, even bypassing participatory consultations with, among others, the social partners, in particular the trade unions (for example, Estonia, Hungary and Slovakia). In other instances, these structural reforms have been required or indeed forced upon these member states by European and international institutions and organisations, such as the European Central Bank (ECB), the European Commission and the

1. For an overview of the ETUI's work on the crisis, see also the ETUI website at http://www.etui.org/Topics/Crisis 
International Monetary Fund (IMF), the so-called 'Troika' (for example, in Greece, Portugal and Spain where the reforms were 'agreed upon' between the Troika and the respective governments in Memorandums of Understanding). In addition, the European Union together with the IMF has undertaken 'missions' to European member states in economic difficulties. In 2010, for example, they went to Latvia to discuss the 2011 budget with the government, insisting that it include measures to deliver lasting deficit reduction, sufficient to bring the general government deficit down below the programme's 2011 ceiling of 6 per cent of GDP, while providing adequate funding for the social and health safety nets, public works employment and job training to alleviate the impact of the crisis on the most vulnerable part of the population. ${ }^{2}$ The EU and the IMF also organise reviews of the economic programmes of the member states they financially support - such as Romania - in order to 'solidify economic growth while maintaining macroeconomic and financial stability'. In this particular case - and among other requirements - the Romanian government must commit itself to reducing its general budget deficit and to reforming state-owned enterprises, including the sale of majority or minority stakes in some companies and the introduction of professional private management. ${ }^{3}$

Interestingly, the European Commission has not had recourse to labour law and fundamental social rights to ascertain the maintenance of minimum social standards; neither has it resorted to hard law mechanisms, although it has the legislative competence to do so under the Treaty. On the contrary, the European Union tends to follow its longstanding trend of calling for labour market 'flexibilisation' (and labour law deregulation), as stated in a Communication in 2010: 'flexicurity policies are the best instrument to modernise labour markets: they must be revisited and adapted to the postcrisis context, in order to accelerate the pace of reform, reduce labour market segmentation, support gender equality and make transitions pay' (European Commission 2010: 2). In addition, DG Financial and Economic Affairs stated that to avoid unnecessary and irreversible destruction of [human and entrepreneurial] capital, ... the EU [will take] the lead in developing guidelines on the design of labour market policies during the crisis' (European Commission 2009: 2), thereby neglecting hard labour law. However, there is no evidence that the financial and economic crisis is the result of labour law provisions in the member states.

The labour law reforms currently being implemented in many Member States are thus justified by the argument that making labour markets more flexible is one of the best responses to the crisis (European Commission 2010). In some countries it consists only of piecemeal although significant deregulatory measures, while in others it involves far-reaching overhauls of the whole labour code. Furthermore, in several countries fundamental changes are being made

2. See: http://ec.europa.eu/economy_finance/articles/eu_economic_situation/2010-12-16staff-visit-latvia_en.htm

3. See: http://europa.eu/rapid/pressReleasesAction.do?reference=MEMO/11/545 
to industrial relations structures and processes which might jeopardise social dialogue and collective bargaining there.

This report maps these labour law reforms in the various member states. The principal objective is to survey and address the legal changes (reforms) being made to labour law regulations in the Member States, which in most cases are presented as necessary means to get out of the economic crisis. Such reforms generally render existing labour law provisions more flexible and loosen minimum standards, shifting the emphasis to soft law (deregulation). The mapping presented here is far from exhaustive, for several reasons. First, it deals only with certain labour law reforms and changes; for instance, it does not consider other anti-crisis measures taken in many countries on (minimum) wage setting/cutting, lowering or even cutting of social security and social assistance protection and benefits, cuts in public services and so on. Second, it deals mainly with developments between the start of 2010 and February 2012. ${ }^{4}$ Third, it does not touch upon all EU/EEA member states or candidate countries. ${ }^{5}$ The latter is due mainly to information constraints, but also because some countries, in accordance with their industrial relations traditions, put less trust in the law and more in the social partners for reform of their labour market systems, such as the Nordic countries.

This Working Paper presents the main trends and tendencies based on a country by country analysis. The country studies are regularly updated and can be found at the ETUI website. ${ }^{6}$ The information used in this paper stems from the following sources: (1) information provided to the ETUC by its affiliated organisations, (2) so-called Memorandums of Understanding certain countries have with the IMF, the EU and the ECB, and (3) other sources, such as the Dublin Foundation's EIROnline website (http://www.eurofound.europa.eu/ eiro/), other (electronic) newsletters (for example, www.planet.labour) and academic articles. The most recent information is from 22 February 2012.

By way of conclusion, the report critically addresses the large-scale deregulation of labour law currently taking place in the European member states, in particular the lack of democratic foundations underlying the reforms and their negative impact on fundamental social rights and workers' protection.

4. An ETUI Policy Brief of 2012 mainly describes how the crisis affected social legislation in the period 2008-2009 (Laulom et al. 2012).

5. The report covers the following countries: Belgium, Bulgaria, Czech Republic, Finland, France, Greece, Hungary, Italy, Ireland, Latvia, Lithuania, Luxembourg, Netherlands, Poland, Portugal, Romania, Slovakia, Slovenia, Spain, Sweden and the United Kingdom. Particular attention is paid to the countries that have signed so-called Memorandums of Understanding with the IMF, the EU and the ECB to set up an Economic Adjustment Programme: Greece (May 2010 and February 2012), Ireland (December2010) and Portugal (May 2011).

6. http://www.etui.org/Topics/Social-dialogue-collective-bargaining/Social-legislation. 


\section{Main trends and tendencies}

Looking at developments in the various countries, four main areas of labour law changes or reforms can be identified.

Fundamental changes to working time (I) and atypical employment (II) are being made, mainly in response to the economic and financial crisis, although such reforms tend to be temporary. There are also reforms of and changes to rules on redundancy (for business reasons) (III) and industrial relations structures and processes (IV), which affects social dialogue and collective bargaining. These reforms tend to be (more) permanent. But whether such changes consist of the overhaul of whole labour codes or piecemeal changes to specific aspects and rules, they undermine the protective role of both individual and collective labour law, thus putting workers in a more precarious and unprotected situation both in general and in the workplace. From a democratic perspective, the fifth trend is even more worrisome. In several countries (V) reforms were introduced without recourse to democratic and participatory (legislative) procedures, but rather using emergency procedures, bypassing parliaments or the social partners.

Table 1 provides a schematic overview of the four main areas in which change and reform have taken place, based on the information collected for this report. In the rest of this section, we try to clarify, by means of examples, the main developments and measures in each area throughout Europe, including the bypassing of democratic and participatory procedures.

\subsection{Working time}

As already mentioned, a first set of changes are related to working time (arrangements) in the broad sense. Overtime comes up very frequently. Several countries have opted, for instance, to widen overtime options, sometimes considerably. For instance, in the Czech Republic, plans are on the table to increase permitted overtime to up to 416 hours per calendar year for managers (now up to 150 hours) and up to 150 hours for other workers. In Hungary, the annual limit of overtime was increased from 200 to 250 hours and even up to 300 hours if set by collective agreement. However, the former 200 hour limit was applicable only to certain workers with so-called 'special skills': now, this extended overtime option is available to all workers. Another major trend in Hungarian labour law reform is decentralisation of collective bargaining, giving a more prominent role to enterprise bargaining compared to national and sectoral bargaining. In Lithuania, overtime was previously prohibited, except 
Table 1 Changes announced and/or adopted to industrial relations/collective bargaining systems and certain aspects of labour law

\begin{tabular}{|c|c|c|c|c|}
\hline & $\begin{array}{l}\text { Reform of industrial } \\
\text { relations and collective } \\
\text { bargaining systems } \\
\text { (including decentralisation } \\
\text { of collective bargaining) }\end{array}$ & $\begin{array}{l}\text { Changes to } \\
\text { individual/collective } \\
\text { dismissal rules }\end{array}$ & $\begin{array}{l}\text { Changes to } \\
\text { organisation of } \\
\text { working time } \\
\text { legislation }\end{array}$ & $\begin{array}{l}\text { Changes to rules on atypical } \\
\text { contracts (including creation } \\
\text { of new types of contract }\left(+^{*}\right) \\
\text { in particular for young } \\
\text { people }\left(+^{* *}\right)\end{array}$ \\
\hline Belgium & & + & + & $+^{* *}$ \\
\hline Bulgaria & + & & & $+\star \star$ \\
\hline Cyprus & & + & & \\
\hline Czech Republic & & + & + & $+^{*}$ \\
\hline Estonia & + & + & & + \\
\hline Finland & + & & & \\
\hline France & + & & & $+* *$ \\
\hline Germany & & & + & + \\
\hline Greece - MoU & + & + & + & $++^{\star *}$ \\
\hline Hungary & + & + & + & $+* *$ \\
\hline Italy & + & + & & $+* *$ \\
\hline Ireland - MoU & + & & & \\
\hline Latvia & & + & & + \\
\hline Lithuania & & + & + & + \\
\hline Luxembourg & & & + & $+* *$ \\
\hline Netherlands & + & & & + \\
\hline Poland & + & & + & $+^{*}$ \\
\hline Portugal - MoU & + & + & + & + \\
\hline Romania & + & + & + & $+/+^{* *}$ \\
\hline Slovak Republic & + & + & + & $+^{*}$ \\
\hline Slovenia & & & + & $+^{*}$ \\
\hline Spain & + & + & + & $+/+^{* *}$ \\
\hline Sweden & & & + & $+^{* *}$ \\
\hline United Kingdom & & + & + & + \\
\hline
\end{tabular}

Note: MoU: countries with a Memorandum of Understanding with the EU, the IMF and the ECB. Source: ETUI research.

in some cases listed in the Labour Code or collective agreements, but in 2010 overtime rules were liberalised, permitting up to 120 hours a year or 180 hours if agreed in collective agreements. Other countries, on the other hand, have opted rather to change the rules on compensation for overtime in time-off or in kind. As provided for in the Memorandum of Understanding between Portugal and the 'Troika', draft legislation was introduced at the beginning of 2012 to amendment the Labour Code, thereby reducing additional pay for overtime by 50 per cent: whereas at present employees are paid 50 per cent extra for the first hour of overtime worked, 75 per cent extra for additional hours and 100 per cent extra for overtime on holidays and Sundays, the rates are now 25 per cent, 37.5 per cent and 50 per cent. Other foreseen amendments are to put an end to compensatory time-off, which at present stands at 25 per cent of overtime hours worked. It is possible to revise these norms upwards or downwards by collective agreements. 
A second popular measure taken or planned in several countries concerns the extension of reference periods for calculating working time. In 2009, in the first wave of its labour law reforms, the Hungarian government allowed employers to set the reference period at four months (instead of three months) and even to extend it to twelve months under certain circumstances by collective agreement. In Poland, under the Anti-crisis law of 2009 reference periods could even temporarily be extended - via company collective agreement - from three to 12 months. With the expiry of this law at the end of 2011, the issue is again on the table, with the employers' side lobbying hard to make the 12-month reference period a rule rather than a temporary exception. In Romania, new Labour Code provisions set the reference period at four months (compared to three previously) and in exceptional cases even allow reference periods of six to 12 months. Other measures taken in the area of working time (arrangements) concern the introduction of short-term working schemes, as in Poland where, in particular, companies experiencing temporary financial difficulties are able - for a maximum of six months - to reduce working time or even to put their workers on (lower paid) 'inactivity leave' because of lack of work, as an alternative to collective redundancies. Similarly, variants of 'short-term working schemes' were introduced in several countries, including Austria, Belgium, Bulgaria, France, Germany and Spain. Such schemes differ considerably from country to country with regard to duration of entitlement, workers covered and so on (see also Glassner et al. 2009 and Glassner 2010).

It is well documented that working long or excessive hours has a serious impact workers' health and safety. After allowing further flexibilisation of working time it might prove difficult to turn the clock back in future, even though these measures are often intended to be only temporary. The fact that exceptions or more flexible arrangements can be established only via collective agreement provides a certain safeguard, but the ongoing trend of collective bargaining decentralisation in many countries, with a preference for enterprise-level bargaining, might mean that it turns out to be inadequate and easily bypassed. Workers' representatives might be faced with having to accept schemes with longer working hours as an alternative to (collective) redundancies.

\subsection{Atypical contracts (fixed-term, part-time and temporary agency work) and the introduction of new types of contract}

A second clear trend comprises efforts by many member states to render their labour market more flexible by changing the rules governing atypical contracts.

One popular means of doing so - despite the existence of a European Directive whose main objective is to prevent the abuse of successive fixed-term contracts ${ }^{7}-$

7. Council Directive 1999/70/EC of 28 June 1999 concerning the framework agreement on fixedterm work concluded by ETUC, UNICE and CEEP, OJ L 175, 10.7.1999, pp. 43-48. 
seems to be to further flexibilise the rules on fixed-term contracts by extending their maximum length. Examples include the Czech Republic (extension from two to three years, with two renewals, yielding a total of nine years during which one can be employed on a fixed-term contract by the same employer), Greece (also from two to three years), Portugal (maximum length three years, previously six months), Romania (maximum length increased from 24 to 36 months, with three successive fixed-term contracts: the first for a maximum of 36 months and the other two for 12 months each; previously three successive contracts were allowed but with a total period of 24 months) and Spain (up to three years, from none previously, and the possibility of an additional year by collective agreement). Another option, besides increasing the maximum length of the fixed-term work period, is to increase the maximum number of renewals of such contracts. Examples include the Netherlands (successive fixed-term contracts for young workers under 27 years of age become permanent after the fifth contract instead of the fourth, as previously) and Poland (undefined number of renewals but a worker can work only up to 18 months for the same employer). Some countries have combined both measures, such as Slovakia, where the maximum length of fixed-term employment is now three years instead of two and three renewals are allowed over three years instead of the previous two.

As for part-time work and measures to further 'flexibilise' it, in Spain the reform programme of February 2012 has abolished a rule that had been in force for about 15 years prohibiting standard overtime for those in part-time employment. In addition to what Spanish law calls 'horas complementarias' (specific overtime for part-timers, subject to some formal requirements and limitations - this form of overtime continues to be lawful), part-timers can now work standard overtime ('horas extraordinarias') like any other employee.

Other countries - including Belgium, the Czech Republic, Greece, Romania and the United Kingdom - have opted to introduce or amend the regulations on temporary agency work. However, this might be more due to the attempts of the countries concerned to implement Directive 2008/104 on temporary agency work (implementation deadline December 2011) and not only deregulatory measures but in some instances more protective measures are involved.

Linked to this re-regulation of atypical contracts in several member states is the creation of new types of contract. This would not be a problem in itself, but these new contracts often offer less protection than normal employment contracts and/or are targeted at specific groups of workers, such as young people, who are already among the most vulnerable as regards labour market entry, progress and retention. A typical example is Greece's introduction of a new 'youth contract'. The idea is to hire young workers up to the age of 25 on wages 20 per cent lower than the previous rate for first jobs, with a two-year trial period, no social contributions for employers and no entitlement to unemployment benefits at the end of the contract. In Spain, a new training and dual education contract has been introduced for unskilled young people aged 25-30 (but with the possibility to extend it to persons aged up to 34), providing considerable exemptions from social security contributions for employers both 
during the contract and upon conversion of the contract into a normal, permanent one.

Apart from the immediate effect that this might have, leading to further labour market segregation and exacerbating the position of vulnerable or precarious workers, who experience serious difficulties in entering, progressing and staying in the labour market, in some cases it is doubtful whether some of these rules and contracts are compatible with European directives, in particular those on fixed-term and part-time work.

\subsection{Redundancy rules}

The global economic crisis has increased redundancies: job cuts are the primary resort of private and public sector companies in reducing wage costs, with cuts in working hours some way behind. This is particularly the case in member states in which legal protection against (collective) dismissal is weak (United Kingdom, Ireland).

Amendments to labour codes/labour regulations on collective and individual redundancies aim mainly at simplifying hiring and dismissal rules (and allowing large-scale recourse to atypical work). Three main areas of legislation are involved, sometimes in combination:

- Review of the definitions of (collective) redundancies and in particular the notion of economic reasons for such redundancies allow more grounds for dismissals, the idea being to enable undertakings to adapt better and more quickly to the market changes (Czech Republic, Portugal, Spain, Slovakia, United Kingdom); Conditions governing dismissals are softened and thresholds are loosened in order to increase labour market flexibility, thus giving enterprises greater autonomy in laying off workers (Estonia, Greece, United Kingdom, Romania).

- Amendments to procedures governing (collective) redundancies are also aimed at flexibilising existing regulations: dismissal procedures have been made easier by reducing advance notice by 30 calendar days to between two weeks and three months, depending on the length of the previous employment contract, including notification (Bulgaria, Estonia, Lithuania, Slovakia, Spain, Portugal, United Kingdom), and/or by allowing more flexible layoffs in SMEs (United Kingdom), weakening employers' obligation to inform and consult workers' representatives (Spain) or loosening third-party intervention procedures, such as recourse to administrative authorisation (Estonia) or reducing employers' obligation to set up social plans (Romania, United Kingdom). Finally, access to employment tribunals has been restricted in the United Kingdom.

- Amendments aimed at more flexible redundancy legislation also affect the cost of layoffs, with a view to reducing the financial burden on undertakings. Severance pay has been reduced (Czech Republic), eligibility 
and qualification periods have been amended to provide more scope for firing workers, redundancy benefits have been reduced (Portugal, Spain) and/or sanctions have been lightened (for example, replacing the sanction of reintegration of employees after wrongful dismissal with financial compensation alone). In addition, in some countries (United Kingdom) charges have been introduced for appeals to employment tribunals. Finally, public funds have been used to support enterprises laying off employees by creating an 'employers' compensation fund' to finance redundancy benefits (for example, in Portugal).

In parallel with this, most labour law reforms have amended not only collective rights pertaining to (collective) redundancy but also atypical work schemes (such as fixed-term work contracts, temporary agency work and so on). This is usually presented as a means of avoiding precariousness and maintaining employment. However, the flexibilisation of employment protection law must be regarded critically, in particular because it will create more (long-term) unemployment and more precariousness on the labour market.

\subsection{Changes to industrial relations and collective bargaining systems}

A clear policy and/or ambition can be identified in many countries to decentralize collective bargaining, shifting from national/sectoral level to company level. The professed aim is to give businesses more flexibility and help them adjust to labour market conditions. Examples can be found in Italy, Greece, Portugal and Spain. In Romania, the annual national collective agreement has been abolished in favour of sectoral collective agreements. In Finland, the decentralisation of bargaining has not proved effective and employers have been encouraged to join the national collective agreement.

Apart from shifting the onus to other levels, there is often the (additional) problem of allowing lower-level bargaining outcomes to deviate unfavourably from the protection provided by higher level collective agreements or even statutory legislation. Such collective agreements in pejus deal, for instance, with working time and wages. Examples of the latter can be found in France, Greece, Italy and the Slovak Republic.

Another trend is the adoption of measures reviewing representativeness criteria for social partners (for example, Greece, Hungary, Italy, the Netherlands, Portugal Romania, Slovakia and Spain) and extending what used to be trade union prerogatives to other bodies of workers' representation (often at company level) (for example, Greece, Portugal and the Slovak Republic).

There are also examples of countries - for example, Hungary - abolishing or at least diminishing the role of certain (tripartite) social dialogue institutions, with the government withdrawing from such bodies (for example, Romania). 
Other labour law reforms tend to impose alternative dispute resolution mechanisms instead of tribunals (Bulgaria, United Kingdom, Spain). In Greece, ${ }^{8}$ arbitration must be triggered by the joint request of the parties and is restricted to basic wage demands. In the United Kingdom, access to labour tribunals has been restricted. Finally, the regulations on collective disputes have been reviewed in some countries.

These reforms of collective labour law will definitely weaken trade union representation and action at all bargaining levels. They affect the very structure of trade unions as well as their institutional means of protecting and representing workers. Decentralisation of collective bargaining to the lowest level weakens the social acquis achieved so far by the trade unions at national and local level and will affect sectoral collective bargaining. It will also lower the standard of rights recognised so far and anchored in legislation and collective agreements, as well as affecting fundamental employment conditions related to working time, pay, work organisation, working environment and social protection. It will also have an impact on health and safety at work.

\subsection{Lack of respect for democratic and participatory foundations and procedures in passing the reforms}

Another striking characteristic of national reforms is the way in which the drafting and hierarchy of social norms have been affected. For example, in some cases, there has been recourse to 'emergency procedures' by national legislators to bypass agreements on 'anti-crisis' measures agreed by the social partners and/or prepared by national governments in consultation with the social partners (Estonia, Hungary, Slovakia). In Greece and Italy, the government bypassed the parliament. In Greece and Portugal, the national authorities have had to implement the Memorandum of Understanding imposed by the European Union, the IMF and the ECB to get access to the socalled 'financial rescue umbrella', and thus without any consultation with the national or European parliament. This, together with the reduction of the role of social partners in drafting social legislation - in particular, the decentralisation of collective bargaining and the new criteria applying to trade union representation - represents an alteration of the procedures governing social legislation at the expense of democracy.

Furthermore, in some cases anti-crisis measures and labour law reforms affect fundamental social rights, directly or indirectly. When looking at Memorandums of Understanding, it is disturbing to read in the 'social policy chapter' - for example, in the Greek Memorandum of Understanding of May 2010 on Specific Economic Policy Conditionality - that

8. As mentioned in the Memorandum of Understanding of February 2012. 
the government shall amend employment protection legislation to extend the probationary period for new jobs to one year; reduce the overall level of severance payments and ensure that the same severance payment conditions apply to blue- and white-collar workers; raise the minimum threshold for activation of rules on collective dismissals especially for larger companies; and facilitate greater use of temporary contracts and part-time work. ${ }^{9}$

Portugal's Memorandum of Understanding on Specific Economic Policy Conditionality of May 2011 states in the section on 'Employment protection legislation' (4.3) that

the government will carry out reforms in the employment protection system aimed at tackling labour market segmentation, fostering job creation, and easing adjustment in the labour market: 4.4. Severance payments; 4.5 Definition of dismissals; 4.8 "organised decentralisation" (notably concerning: (i) the possibility for works councils to negotiate functional and geographical mobility conditions and working time arrangements).$^{10}$

Furthermore, a number of national measures taken within the framework of labour law reforms run counter to labour law principles, not least the principle of trade union autonomy and trade union freedom (Spain, Greece), and even the right to equality and non-discrimination (United Kingdom). Such procedures call in question the legitimacy of the national reforms because the lawfulness of the procedures (that is, their respect for democratic procedures) has been marginalised and/or they violate fundamental rights and freedoms at European level. Indeed, in Spain and Greece the trade unions have brought a complaint before the ILO and the Council of Europe.

Currently, the 'first' anti-crisis measures are under review and discussions are taking place on the need to make temporary measures permanent (Germany, Greece and Spain). In some cases, the positive impact of anti-crisis measures is being questioned. In other cases, labour law reforms have been adopted with no link - direct or indirect - to the economic and financial crisis, thus following a deregulatory path. Parallel to the reform of collective labour law, we are witnessing a widespread failure to implement information and consultation procedures in the case of restructuring dismissals and without any intervention by the European Commission (ETUC SDA 2011).

9. Memorandum of Understanding of 2 May 2010 between Greece and the EU, the IMF and the ECB, p. 10.

10. Memorandum of Understanding of 3 May 2011 between Portugal and the EU, the IMF and the ECB, pp. 20-22. 


\section{Conclusions}

The report demonstrates the major negative impact of labour law reforms on workers' rights and fundamental social rights under cover of the economic and financial crisis. National reforms tend to deregulate already flexibilised labour law regulations and thus in most cases represent a step backwards in terms of workers' protection. A recurrent feature of these labour law reforms and flexibilisation is the explosive growth of inequalities and insecurity in most of the countries concerned (Laulom et al. 2012: 5). Setting this alongside measures affecting social security, such as pension reforms or public sector reforms, reduction of job seekers benefits, salary cuts and so on, calls into question the European concept of 'quality employment' and the international concept of 'decent work', which national labour law reforms in Europe no longer seem to meet. The meaning of the European social model is also undermined.

Furthermore, the report shows that in most cases the procedures do not respect democratic traditions in the member states, thereby jeopardising the reforms' legitimacy. So far, however, only two national trade unions in Spain and Greece have filed a complaint to the ILO that collective bargaining reforms run counter to principles of trade union freedom and/or free collective bargaining. Interestingly, the European Commission has not yet reacted to measures violating fundamental rights of the kind guaranteed in the Treaty and in the Charter of Fundamental Rights. More worrying is the fact that the $\mathrm{EU}$, as party to the memorandum of understanding signed with Greece, Ireland and Portugal and also as party to additional financial programmes supporting European member states (Latvia, Romania) is putting so much pressure on the member states to reform their labour law and social protection, using the vague wording of the Treaty to support such reforms (see Art. 122.2 TFEU).

Labour law reforms tend to adjust labour regulations in the member states designed to combat precarious employment, labour market segmentation and a certain labour law rigidity, taking it for granted that these have a negative impact on productivity and employment. The aim is therefore to flexibilise labour law protections perceived as too complicated, too expensive and too burdensome for enterprises. However, as pointed out in Finland during negotiations on a national agreement in October 2011, it has not been proven that such reforms - here, the decentralisation of collective bargaining - work. Furthermore, the assumption that labour law reforms in Europe are needed to exit from the crisis can be questioned, as it is difficult to distinguish whether labour law reforms are a response to the economic crisis or merely accompany 
the crisis, with no certainty about any causal link between them. ${ }^{11}$ Indeed, at present the reforms seem to be giving rise to increased precariousness but no more employment. Labour law reforms supported by the European Union are confirming the trend according to which quality employment is perceived as being incompatible with competitiveness. This indirectly affects labour law protection and emphasises economic freedoms, at the expense of democratic traditions in Europe.

There is clear evidence of a 'deconstruction' of labour law under the guise of the economic crisis. Our hope is that, besides functioning as a mapping exercise, bringing together information on the various reforms already implemented or ongoing in the member states, this report may also serve as an important warning signal and help to raise awareness among all relevant actors and institutions of the fact that closer monitoring of these reforms is necessary. The European trade union movement, in particular ETUC and its affiliates, fears that some of them run counter to the countries' obligations under fundamental ILO, Council of Europe and EU norms and standards. In fact, in some countries the trade unions have reacted not only by demonstrating or organising general strikes but also by filing complaints to the respective ILO and Council of Europe authorities concerning alleged violations by these reforms (for example, Greece, Hungary and Slovakia). All other relevant reforms should be scrutinised in relation to international and European norms.

The ETUI will continue to conduct such monitoring, gather the necessary information and review, amend and complement the information contained in this report.

11. Valdés Dal Rés (2011) and Jeammeaud (1997). 


\section{References/sources}

\section{Electronic newsletters/websites}

Planet Labor - http://www.planetlabor.com (reference period 2010-2011)

Eironline - http://www.eurofound.europa.eu/eiro/ (reference period 2010-2011)

Epsucob@NEWS - Collective Bargaining in the Public Services - http://www.epsu.org/ (mainly 2011)

ETUI-AIAS Collective Bargaining newsletter - http://www.etui.org/E-Newsletters/ Collective-bargaining-newsletter - (reference period 2010-2011)

ETUC website section on economic and social crisis - http://www.etuc.org/r/1378 ETUI website section on crisis - http://www.etui.org/Topics/Crisis

\section{Periodicals}

Social International (editions 2010 and 2011)

\section{Others}

Abelleira, F. (2012) Comments on the latest labour reform in Spain, Planet Labour focus, February 2012 (available at http://www.planetlabor.com/Articles/ plonearticle.2012-02-21.9178889219/)

Belgian Government (2011) Projet de Déclaration de Politique Générale, Bruxelles, 1 décembre 2011

CCOO (2012) A labour reform designed only to satisfy employers and financial markets, CCOO Info Boletin electronico, $\mathrm{N}^{\mathrm{o}} 30$, Madrid, $16^{\text {th }}$ of February 2012

Degryse, C and Pochet, P. (2011) Monetary Union, economic coordination and democratic legitimacy. ETUI Policy Brief, 5, 2011.

Dimitru, R. (2011) Romanian labour legislation in a time of change, European Labour Law Journal, Volume 2 (2011), $\mathrm{n}^{\circ}$ 2, pp. 173181

Duffy, K. and Walsh, F. (2011) Independent Review of Employment Regulation Orders and Registered Employment Agreement Wage Setting Mechanisms, Dublin, April 2011 (available at: http://www.djei.ie/publications/employment/2011/Report_ ERO_REA.pdf)

ETUC SDA (2011) Restructurations des entreprises multinationales pour répondre à l'impact de la crise par une coordination syndicales transnationales plus forte

European Commission (2010) Communication on 'An Agenda for new skills and jobs: A European contribution towards full employment' COM(2010) 682 final.

European Commission (2009) Economic crisis in Europe: causes, consequences and responses.

http://ec.europa.eu/economy_finance/publications/publication15887_en.pdf

Martin Puela, E. (2011) 'Les réactions du droit du travail à la crise économique', 'Espagne: radiographie d'une réforme'. Revue de Droit du Travail, $\mathrm{n}^{\circ}$ 9, septembre 2011, 521-530.

Foundation $1^{\circ}$ de Mayo (2012), Fifty two labor market reforms since the adoption of the Statute of Workers in 1980, Foundation « $1^{\circ}$ de Mayo" publications: Labour market reforms in Spain and its impact on recruitment and employment, February 2012 (Available at: www.1mayo.ccoo.es) 
G20 (2011a) G20 Labour and Employment Ministers' Conclusions - Paris, 26-27 September 2011 (available at: http://www.ilo.org/global/about-the-ilo/how-the-iloworks/multilateral-system/g20/WCMS_16426o/lang--fr/index.htm)

G20 (2011b) G20 Heads of State Cannes Summit Final Declaration "Building our common future: Renewed collective action for the benefit of all”, Cannes, 4 November 2011

Glassner, V. (2009) Government and trade union responses to the economic crisis in the financial sector, ETUI Working Paper 2009.09, Brussels: ETUI

Glassner, V. and GalgÓczi, B. (2009) Plant-level responses to the economic crisis in Europe, ETUI Working Paper 2009.01, Brussels: ETUI

Glassner, V. (2010) The public sector in the crisis, ETUI Working Paper 2010.07, Brussels: ETUI

ILO (2011a) Memorandum of Technical Comments on the draft Labour Code and the Draft Law on Social Dialogue of Romania, Geneva, 17 January 2011

ILO (2011b) Report on the High Level Mission to Greece (Athens, 19-23 September 2011), Geneva, 22 November 2011

Jeammaud, A. (1997) 'Crise et relations du travail' in Droit de la crise, crise du droit ? Les incidences de la crise économique sur l'évolution juridique”, Paris PUF, p. 96.

Laulom, S, Mazuyer, E. Teissier, C, Triomphe, C.E. and Vielle, P. (2012) How has the crisis affected social legislation in Europe? ETUI Policy Brief 2, 2012, Brussels: ETUI.

Leschke, J. and Watt, A. (2010) How do institutions affect the labour market adjustment to the economic crisis in different EU countries?, ETUI Working Paper 2010.04, Brussels : ETUI

LIGA (2011) LIGA Newsletter, 1 September 2011, p. 4-11

Memorandum of Understanding of $2^{\text {nd }}$ May 2010 between Greece and the EU, IMF and ECB

Memorandum of Understanding of 10 December 2010 between Ireland and the EU, IMF and ECB http://ec.europa.eu/economy_finance/articles/eu_economic_ situation/2010-12-01-financial-assistance-ireland_en.htm

Memorandum of Understanding of $3^{\text {rd }}$ May 2011 between Portugal and the EU, IMF and ECB. http://www.fedea.net/portugal/memorandotroika_04-05-2011.pdf

Mitrus, L. (2010) Anti-crisis regulation of Polish Labour Law, European Labour Law Journal, Volume 1 (2010), $\mathrm{n}^{\circ} 2$

Muller, A. (2011) Employment protection legislation tested by the economic crisis: A global review of collective dismissals for economic reasons. Dialogue in Brief, No. 3, September 2011, ILO, Geneva

Natali, D. (2011) Pensions after the financial and economic crisis: a comparative analysis of recent reforms in Europe, ETUI Working Paper 2011.07, Brussels : ETUI

O'Farrell, R. (2010) Wages in the crisis, ETUI Working Paper 2010.03, Brussels: ETUI

Tajgman, D. , Saget C., Elkin, N. and Gravel, E. (2011) Rights at work in times of crisis: Trends at the country level in terms of compliance with international labour standards, Employment Sector, Employment Working Paper $N^{\circ}$ 101, ILO Geneva: 2011 (available at: http://www.ilo.org/employment/Whatwedo/Publications/ working-papers/WCMS_167804/lang--en/index.htm)

Valdés Dal Rés, F. 2011. 'La ley de reforma del Mercado de trabajo: las singularidades de su objeto y los equivocos de sus objetivos’ Relaciones laborales, n.6, 2011,pp.1-7;

\section{As well as contributions by ETUC affiliated organisations at the following meetings:}

ETUC Social Policy and Legislation Ad hoc working group - 13 November 2011 ETUC Legal Experts Network NETLEX Annual Conference 2011 - 1-2 December 2011 
European

Trade Union Institute

Bd du Roi Albert II, 5

1210 Brussels

Belgium

Tel.: +32 (0)2 2240470

Fax: +32 (0)2 2240502

etui@etui.org

www.etui.org 